\title{
Public tendering process for construction projects: problem identifications, analysis, and proposed solutions
}

\author{
Eryana Indah Kusumarukmi ${ }^{1}$ and Tri Joko Wahyu Adi $^{2}$ \\ ${ }^{1}$ Master Student in Civil Engineering Department at Institut of Technology Sepuluh Nopember Surabaya, Sukolilo, Indonesia \\ ${ }^{2}$ Lecturer in Civil Engineering Department at Institute of Technology Sepuluh Nopember Surabaya, Sukolilo, Indonesia
}

\begin{abstract}
The current tendering process has vulnerabilities that can be exploited to negatively impact project delivery. There are many research papers that discussed the occurrences of these exploitations (i.e., funds embezzlement, fraud invoicing, etc.), but there has not been one that focused on the study of the tendering process itself, nor presented problem analysis and mitigation options. The aims of this research are to identify and analyze problems in every stage of public tendering process, then offer potential solutions to resolve or curb these problems. In addition to utilizing publicly available studies and interviews were used as starting point of problems identifications. Questionnaires were then distributed to tendering practitioners. Likert scale assessment and factor analysis were used to measure the questionnaires and analyze the data respectively, while proposed solutions were established from experts' judgement. This study showed that there are 135 problems that occur during tendering process. The most common problem is the bidding system's inability to provide a complete database of contractors with their personnel, past works and-experiences, and performance evaluation. The limited human resources in both number and competency is another important issue to consider. Proposed solution to solve these issues are based on four pillars of reformation concept done by public procurement agency.
\end{abstract}

\section{Introduction}

Construction Industry is a developing industry. Based on The US Bureau of Labor Statistics Data and Timetric's Construction Intelligence Center (CIC) report, construction industry will become one of the fastest growing industries by 2020 . Indonesia is a developing country, performing a sustainable national growth especially in infrastructure construction through central and local goverment programs. These programs generates unstoppable construction industry in Indonesia. Qualified and competent service providers, such as consultant and contractor, are needed to establish a succesfull infrastructure construction.

The selection and evaluation of contractor play important role and needs great attention, especially for public construction projects that are conducted by the goverment. Contractor evaluation and selection are important and significant for goverment organisation responsible for the succes of construction procces [1]. Choosing competent contractor is important to deliver construction project success [2]. With tight regulations and procurement ethics, tendering process should run smoothly based on expected principles and objectives. On the contrary, however, since procurement process involved many stakeholders and new technology, it encounters a lot of constraints and problems. The study utilized reviews about construction procurement procedure to find out fraud indication and whether eprocurement could reduce the fraud [3]. That same review stated that every construction life cycle, including tender process, had plentiful problems and corruption so accountability is needed [4].

One of the most frequently encountered behaviors acted by service provider was collusion [5]. It often occured in terms of commission to win tender [5]. Conspiracy was often occured in the process of tender [6]. Furthermore, increasing e-procurement creates potential fraudulence [7]. Research showed that e-procurement process in Portugal had several problems, such as lack of technology understanding, and human resources training, and they could impact transparency, value tendering, competency, time, cost and bureaucracy on eprocurement process [8]. There are still many practices that trigger criminal actions in government goods and services procurement [9]. Public tender had often dealing with several problems such as unqualified participant, counterfeiting qualified document or unrealistic cost tender [10]. Eventhought e-procurement has been conducted, but it has not been able to detect distortion [11]. Furthermore, the process had many problems and distortion [12]. Another research explained that it was difficulty to detect and prevent cheating on public procurement especially collusion behavior among participants, The complexity and confusing procurement

\footnotetext{
e-mail : eryana imdah_k@yahoo.com

${ }^{2}$ e-mail : trijokowahyuadi@gmail.com
} 
mechanism, with unclear and overlapping jurisdiction, asimetric information and confict of interests, resulted in the continued expansion of this corrupt behavior [13].

\section{Research Objective}

Based on the above findings, this study was conducted to identify problems that occur specifically in each phase and stages of the procurement process in construction projects tender. These problems are not only derived from the behavior of irregularities or fraud but all things that can hinder the purpose of procurement, including systems, infrastructure, human resources, procedures and policies/ rules. This research was conducted specifically on each tendering stage and phase of construction project so that identification of problem and analysis to find alternative mitigation is easy to do since each stage shows clearly, the time stamps, procedure and party involved.

\section{Procurement of Government's Goods and Services}

Procurement of goods and services is an activity to obtain goods/services by ministry/institution/regional unit/other finstitution. The process starts from planning requirement until completion of all activities to obtain goods/services [14]. Similarly, procurement of government's goods/ services is the procurement of goods/services funded partly or fully from loans or grants within the country received by the government. The execution of procurement of goods/services is conducted through selfmanagement and/or selection of goods/service providers. Moreover, the organisational unit which manages the execution of goods and services procurement consists of budget user /proxy of budget user, commitment-making officer (PPK) as project manager in goverment representative, procurement services unit/procurement official (ULP), which includes procurement team work (pokja) and procurement result examination officer/committee. The procurement discussed in this study is the process of selecting providers through the selection of contractor and referred as construction tender.

The method of contractor selection are public tender, limited tender, direct elections, direct appointments and direct procurement [14]. Public tender is the methode of contractor selection to choose a service provider among all qualified participating service providers in the selection stage. Direct election is the procurement of contractor selection for non-complex contruction with a maximum procurement value of five billion rupiah. Basically the method of selecting service providers in goverment area is conducted by using public tender with post qualification [14]. The selection methods discussed in this study are public tender and direct election with post qualification

\section{Public tendering process for construction projects}

The implementation of post qualification public tendering in Indonesia consists of two phases. They are bid preparation and bidding process execution. Each phase consists of 6 and 13 stages [15], as seen in table 1 . In Indonesia, tendering is implemented electonically or called e-procurement. E-procurement is goods and services procurement which applies Information technology and electronic transaction in accordance with the laws and regulations [14]. E-procurement in selection of construction service provider is called e-tendering. Etendering is the procedure for the selection of construction providers which is conducted openly and can be followed by all providers of goods/services which registered in electronic procurement system. In one construction package tender, contractor may only submit one bidding document in a specified time [14].

Table 1. Phase of contractor selection in post qualification public tendering with one file.

\begin{tabular}{|c|c|}
\hline Phase & Stage \\
\hline \multirow[t]{6}{*}{$\begin{array}{l}\text { A. Bid } \\
\text { preparation }\end{array}$} & $\begin{array}{l}\text { 1. Planning of goods/service providers } \\
\text { selection }\end{array}$ \\
\hline & 2. Selection of procurement system \\
\hline & $\begin{array}{l}\text { 3. Determining method for } \\
\text { qualification evaluation }\end{array}$ \\
\hline & $\begin{array}{l}\text { 4. Determining schedule for selecting } \\
\text { goods/services provider }\end{array}$ \\
\hline & $\begin{array}{l}\text { 5. Drawing out of goods and services } \\
\text { procurement document }\end{array}$ \\
\hline & 6. Determining owner estimated \\
\hline \multirow{14}{*}{$\begin{array}{l}\text { B. Bidding } \\
\text { process }\end{array}$} & Post qualification, one file: \\
\hline & 1. Announcement \\
\hline & $\begin{array}{l}\text { 2. Registration and bidding documents } \\
\text { obtaining }\end{array}$ \\
\hline & 3. Information session (aanwijzing) \\
\hline & 4. Bid document submission \\
\hline & 5. Bid document solicitation \\
\hline & 6. Bid evaluation \\
\hline & 7. Qualifications evaluation \\
\hline & 8. Qualification verification \\
\hline & 9. Preparing minutes of tender results \\
\hline & 10. Determining tender winner \\
\hline & 11. Award announcement \\
\hline & 12. Disclaimer \\
\hline & 13. Refusal of appeal (if required) \\
\hline
\end{tabular}

\section{Research Methodology}

Exploratory research method was selected for this study based on the background information, form of problems, and the research goals. The purpose of exploratory research is to gain more information and new set of data to develop an improved method for future study. The methods used for this paper consisted of literature review, in-depth interviews with personnel who are actively involved with the public procurement process, and distributed questionnaires. Likert scale assessment and factor analysis were used to measure the questionnaires and analyzed the data respectively, while proposed solutions were established from experts' judgement. Research methodology can been seen more clearly in Figure 1. 


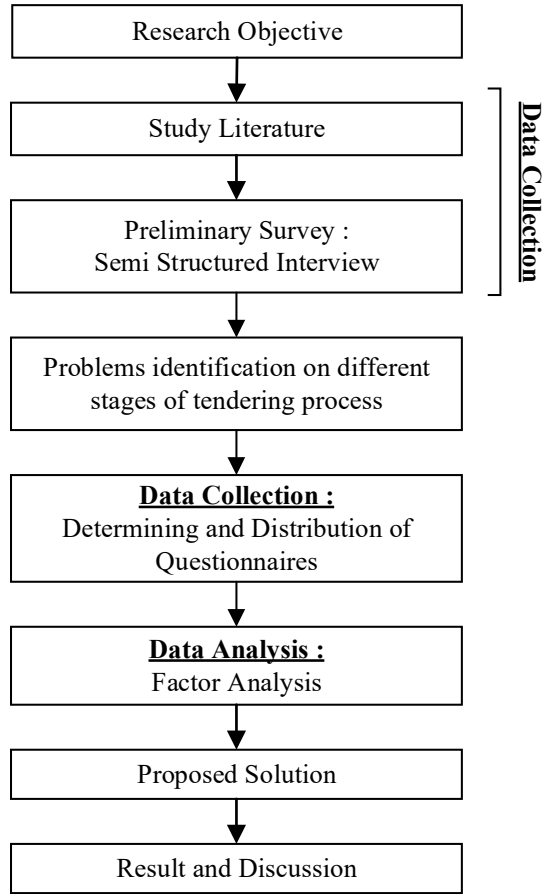

Figure 1. Flow Chart of Research Methodology

\subsection{Literature review}

Literature review was conducted to identify different problems that had occurred in construction public tendering work. Ten research papers and one reference book were used as the basis of 26 identified problems in tendering process. Table 2 shows the list of these problems and their corresponding source.

\subsection{Semi - structured interviews}

To Gain information in exploratory research, at least 15 to 20 respondent with tendering process experience are needed [16, 24]. In this Study, semi-structured interviews were carried out directly with 30 respondents who were still actively involved in the practice or overseeing the public tendering, and who had possessed a minimum of two years' experience. They included commitmentmaking officer, procurement service unit leader and members, procurement working group, contractors, and auditors.

Experienced respondents were selected with the expectation that they would be able to share the problems they frequently encountered in public tendering process. The type of questions asked in the interview were openended; designed to dig deep the problems that had been categorized in different stages of tendering process and the effects of these problems. It started off with a question to a respondent, followed by more probing questions based on the answers given [25].

The aims of these interviews were to compile information on public tendering process, identify the groups involved in the process, and the problems that took place
Table 2. Problem Identified based on previous study

\begin{tabular}{|c|c|c|}
\hline No & Construction Bidding Issue & Reference \\
\hline 1 & $\begin{array}{l}\text { Corruption in terms of providing } \\
\text { payments to gain profits or avoid losses } \\
\text { during the tender process }\end{array}$ & $([4],[17])$ \\
\hline 2 & $\begin{array}{l}\text { Provision of commission and } \\
\text { compensation to win the tender }\end{array}$ & $([5],[18])$ \\
\hline 3 & $\begin{array}{l}\text { Initial bidding document outside the } \\
\text { tender process }\end{array}$ & [5] \\
\hline 4 & $\begin{array}{l}\text { Collusion in term of reduction contract } \\
\text { price for the procurement manager by } \\
\text { contract awarded. }\end{array}$ & [5] \\
\hline 5 & $\begin{array}{l}\text { The price evaluation has no clearly } \\
\text { basis and criteria }\end{array}$ & [19] \\
\hline 6 & $\begin{array}{l}\text { The mechanism of objections and } \\
\text { appeals that are of limited scope. It } \\
\text { only allow the tender participants to } \\
\text { refute the tender result but not to } \\
\text { provide prospective bidders who feel } \\
\text { disadvantaged by the procurement } \\
\text { documents }\end{array}$ & [17] \\
\hline 7 & $\begin{array}{l}\text { compounding or breakdown of work } \\
\text { packages with a specific purpose }\end{array}$ & $([18],[20])$ \\
\hline 8 & $\begin{array}{l}\text { mark up in determining Owner } \\
\text { Estimate }\end{array}$ & $\begin{array}{c}([18],[20], \\
[21])\end{array}$ \\
\hline 9 & $\begin{array}{l}\text { Collusion between providers and } \\
\text { procurement officer }\end{array}$ & $\begin{array}{c}([18],[20]- \\
[22])\end{array}$ \\
\hline 10 & $\begin{array}{l}\text { Using other company's name to join } \\
\text { the tender process }\end{array}$ & [12] \\
\hline 11 & $\begin{array}{l}\text { The pattern of bid document in the } \\
\text { framework of unfair competition }\end{array}$ & [12] \\
\hline 12 & $\begin{array}{l}\text { Political intervention or controlled by } \\
\text { others }\end{array}$ & {$[20]$} \\
\hline 13 & $\begin{array}{l}\text { The procurement plan leads to a } \\
\text { particular product or contractor }\end{array}$ & $([20],[21])$ \\
\hline 14 & $\begin{array}{l}\text { The execution contruction timeframe } \\
\text { of the tendered is unrealistic }\end{array}$ & [20] \\
\hline 15 & $\begin{array}{l}\text { The procurement committee is unfair, } \\
\text { dishonest and unprofessional }\end{array}$ & [20] \\
\hline 16 & $\begin{array}{l}\text { Partner documents are incomplete or } \\
\text { not eligible }\end{array}$ & {$[20]$} \\
\hline 17 & Unfair qualification criteria & [20] \\
\hline 18 & $\begin{array}{l}\text { Bidding document does not meet the } \\
\text { specified standards }\end{array}$ & {$[20]$} \\
\hline 19 & Incomplete tender document & [20] \\
\hline 20 & The announcement period is too short & [20] \\
\hline 21 & $\begin{array}{l}\text { There is no communication between } \\
\text { PPK, Pokja, and Expert team at tender } \\
\text { process }\end{array}$ & $([20],[23])$ \\
\hline 22 & $\begin{array}{l}\text { Excessive technical requirements over } \\
\text { construction project tendered }\end{array}$ & {$[20]$} \\
\hline 23 & $\begin{array}{l}\text { Bidding time frame is too short, } \\
\text { especially when it is too close to the } \\
\text { end of fiscal year }\end{array}$ & {$[20]$} \\
\hline 24 & Proforma tendering & $([21],[22])$ \\
\hline 25 & $\begin{array}{l}\text { Falsification of qualification } \\
\text { documents }\end{array}$ & $([21],[22])$ \\
\hline 26 & Leak of the lowest bid value & [22] \\
\hline
\end{tabular}

Source : researcher study, 2018 


\subsection{Problems identification on different stages of tendering process}

The identification of problems gained from literature research and semi - structured interviews were categorized in different stages based on the type of tasks involved in each process as per regulation. Relevance test then conducted by asking experts' opinions. The experts were asked yes-or-no questions related to the problems. The experts were also asked their feedback about the tendering prosess problems that had not been identified from the literature study and interview. In addition, They were being asked to express their opinions on the impact of the problems that occur. The result of problems identification would be used as material for preparing the questionnaire. The respondents consisted of 7 experts from LKPP, IAPI, Pokja ULP, ULP leader and auditor. 7 expert opinions have been sufficient in obtaining valid and relevant data [26]. The result of problems identification was devided into two stages of tendering process: bid preparation and bidding phase

\subsection{Determining and Distribution Questionnaires}

The questionnaire aimed to determine the frequency and significant impact of construction bidding issue at each construction tendering phase. Closed questions were presented in the questionnaire. Questions were based on the construction bidding issue that occurs during process tendering. Likert scale assessment and factor analysis were used to measure the questionnaires. A 5-point numerical scale were utilized in the questionnaires to measure respondent's perception of the frequency of bidding issue. They were categorized as: very rare (1 point), rarely ( 2 point), occasionally( 3 point), frequently (4 point) and very frequently ( 5 point). Questionnaires were distributed to all stakeholders who were actively involved with the tendering process, including PPK, Pokja ULP, contractors, consultants, and internal / external auditor located in East Java and Bali.

200 Questionnaires were distributed to all stakeholders. Only 155 Questionnaires were accepted from the respondents.

\subsection{Proposed solutions}

Proposed solutions were established from the experts' judgement who had at least 5 years working experience in tendering process These experts consistsed of national public procurement agency (LKPP) officer, member of Indonesian procurement expert organization (IAPI), member or leader of Pokja ULP, and Auditor in Government internal supervisory apparatus (APIP).

\section{Result and Discussion}

\subsection{Construction Bidding Issue during Tendering Process.}

Based on the literature review, semi-structured interview as well as the identification of construction bidding issue with the expert opinion, 50 issues that occurred during preparation stage and 85 issues during bidding process could be obtained. The number of issue that occurs in each stage of tendering process is shown in table 3 and 4.
Table 3. Number of Construction bidding Issue during bid preparation

\begin{tabular}{|c|l|c|}
\hline No & \multicolumn{1}{|c|}{ Phase and Stage } & Number \\
\hline I & $\begin{array}{l}\text { Planning of goods/service providers } \\
\text { selection }\end{array}$ & 10 \\
\hline II & Selection of procurement system & - \\
\hline III & $\begin{array}{l}\text { Determining method for } \\
\text { qualification evaluation }\end{array}$ & 8 \\
\hline IV & $\begin{array}{l}\text { Determining schedule for selecting } \\
\text { goods/services provider }\end{array}$ & 3 \\
\hline V & $\begin{array}{l}\text { Drawing out of goods and services } \\
\text { procurement document }\end{array}$ & 17 \\
\hline VI & Determining owner estimated & 12 \\
\hline & Total number of Issues & $\mathbf{5 0}$ \\
\hline
\end{tabular}

Source : researcher study, 2018

Table 4. Number of construction Bidding Issue during bidding

\begin{tabular}{|c|l|c|}
\hline No & \multicolumn{1}{|c|}{ Stage } & Number \\
\hline I & Announcement & 4 \\
\hline II & $\begin{array}{l}\text { Registration and bidding documents } \\
\text { obtaining }\end{array}$ & 7 \\
\hline III & Information session (aanwijzing) & 12 \\
\hline IV & Bid document submission & 10 \\
\hline V & Bid document solicitation & 7 \\
\hline VI & Bid evaluation & 12 \\
\hline VII & Qualifications evaluation & 12 \\
\hline VIII & Qualification verification & 11 \\
\hline IX & $\begin{array}{l}\text { Preparation of Minutes of Tender } \\
\text { Results }\end{array}$ & - \\
\hline X & Determining tender winner & 2 \\
\hline XI & Award announcement & - \\
\hline XII & Disclaimer & 4 \\
\hline C & Rules/regulation & $\mathbf{8 5}$ \\
\hline & Total number of problems \\
\hline
\end{tabular}

Source : researcher study, 2018

\subsection{Data Analysis}

Factor analysis was used to measure the questionnaires and analyze the data. Factor analysis is data analysis which can reduce the research variable into new form factor. Factor is the formation variable or latent variable of the observed variable [27]. Statistical Product and Service Solutions (SPSS) software was used to conduct factor analysis. The data compiled from the questionaires were entered into the software. After factor analysis function was run, the software would output loading factor for each variable. The output of factor analysis at planning of good/service provider selection stage with SPSS show in Table 5.

The relationship of each variable to the underlying factor is expressed by the so-called factor loading. The variable with the strongest association to the underlying latent variable are factor 1, are problem A1.1 to A1.6. and factor 2 are problem A1.7 to A1.10. With the result that 10 bidding issued were formed 2 new factors that represent 10 issued. 
Table 5. Loading Factor after Rotated component matrix

\begin{tabular}{|l|l|l|}
\hline \multirow{2}{*}{$\begin{array}{c}\text { Problem } \\
\text { Code }\end{array}$} & \multicolumn{2}{|l|}{ Component } \\
\cline { 2 - 3 } & $\mathbf{1}$ & $\mathbf{2}$ \\
\hline $\mathrm{A} 1.1$ & $\mathbf{0 , 8 0 0}$ & 0,180 \\
\hline $\mathrm{A} 1.2$ & $\mathbf{0 , 7 6 2}$ & 0,298 \\
\hline $\mathrm{A} 1.3$ & $\mathbf{0 , 8 0 1}$ & 0,309 \\
\hline $\mathrm{A} 1.4$ & $\mathbf{0 , 6 9 6}$ & 0,500 \\
\hline $\mathrm{A} 1.5$ & $\mathbf{0 , 7 2 1}$ & 0,383 \\
\hline $\mathrm{A} 1.6$ & $\mathbf{0 , 7 9 4}$ & 0,384 \\
\hline $\mathrm{A} 1.7$ & 0,340 & $\mathbf{0 , 6 9 5}$ \\
\hline $\mathrm{A} 1.8$ & 0,297 & $\mathbf{0 , 8 0 3}$ \\
\hline $\mathrm{A} 1.9$ & 0,234 & $\mathbf{0 , 8 4 3}$ \\
\hline $\mathrm{A} 1.10$ & 0,356 & $\mathbf{0 , 7 3 3}$ \\
\hline
\end{tabular}

Source : analysis result by SPSS, 2018

Factor analysis performed for each stage that has at least has 7 number of variable problems. The results of factor analysis is shown in Table 6 and 7.

Table 6. Factor analysis Result of Construction Bidding Issue during bid preparation

\begin{tabular}{|c|l|c|c|}
\hline No & \multicolumn{1}{|c|}{ Stage } & $\begin{array}{c}\text { Number } \\
\text { of Issue }\end{array}$ & $\begin{array}{c}\text { Factor } \\
\text { Analysis }\end{array}$ \\
\hline I & $\begin{array}{l}\text { Planning of goods/service } \\
\text { providers selection }\end{array}$ & 10 & 2 \\
\hline II & $\begin{array}{l}\text { Selection of procurement } \\
\text { system }\end{array}$ & - & - \\
\hline III & $\begin{array}{l}\text { Determining method for } \\
\text { qualification evaluation }\end{array}$ & 8 & 8 \\
\hline IV & $\begin{array}{l}\text { Determining schedule for } \\
\text { selecting goods/services } \\
\text { provider }\end{array}$ & 3 & 3 \\
\hline V & $\begin{array}{l}\text { Drawing out of goods and } \\
\text { services procurement } \\
\text { document owner }\end{array}$ & 12 & 12 \\
\hline VI & $\begin{array}{l}\text { Determining } \\
\text { estimated }\end{array}$ & $\mathbf{5 0}$ & $\mathbf{2 8}$ \\
\hline & Total number of Issues \\
\hline
\end{tabular}

Source : researcher study, 2018

There was a significant changes in table 6 regarding the number of bidding issue at first and fifth stages. In first stage, 10 bidding issues were reduced into 2 new issues, whereas in fifth stage, 17 issues were reduced into 3 new issues. It can be seen that after factor analysis was conducted, 50 problem variables of the bidding issue were reduced to 28 problems. The same procedure was also being done in bidding proces phase where the original 85 problems were reduced to 46 problems, as shown in Table. 7.
Table 7. Faktor analysis Result of Construction Bidding Issue during bidding execution

\begin{tabular}{|c|l|c|c|}
\hline No & \multicolumn{1}{|c|}{ Stage } & $\begin{array}{c}\text { Number } \\
\text { of Issue }\end{array}$ & $\begin{array}{c}\text { Factor } \\
\text { analysis }\end{array}$ \\
\hline I & Announcement & 4 & 4 \\
\hline II & $\begin{array}{l}\text { Registration and bidding } \\
\text { documents obtaining }\end{array}$ & 7 & 7 \\
\hline III & $\begin{array}{l}\text { Information session } \\
\text { (aanwijzing) }\end{array}$ & 12 & 2 \\
\hline IV & Bid document submission & 10 & 10 \\
\hline V & Bid document solicitation & 7 & 7 \\
\hline VI & Bid evaluation & 12 & 2 \\
\hline VII & Qualifications evaluation & 12 & 2 \\
\hline VIII & Qualification verification & 11 & 2 \\
\hline IX & $\begin{array}{l}\text { Preparation of Minutes of } \\
\text { Tender Results }\end{array}$ & - & - \\
\hline X & $\begin{array}{l}\text { Determining } \\
\text { winner }\end{array}$ & 2 & 2 \\
\hline XI & Award announcement & - & - \\
\hline XII & Disclaimer & 4 & 4 \\
\hline C & Rules/regulation & 4 & 4 \\
\hline & Total number of Issues & $\mathbf{8 5}$ & $\mathbf{4 6}$ \\
\hline
\end{tabular}

Source : researcher study, 2018

\subsection{Result and Discussion}

SPSS software was also used to generate the average point of each problem variable and rank them accordingly. Based on the new construction bidding problem, the issue is quite dominant and frequently occurs with an average value above 2.0. In the preparation phase, there are 6 problems in 3 stages that frequently occur from a total of 28 problems, as shown in table 8 . In the bidding phase, there are 11 problems in 6 stages that frequently occur from 46 problems, as shown in table 9 .

Table 8. Most Frequent Issues during Bid Preparation Stage

\begin{tabular}{|c|c|c|c|}
\hline No & \multicolumn{2}{|c|}{$\begin{array}{c}\text { Construction Bidding Issue at Bid } \\
\text { Preparation Phase }\end{array}$} & Mean \\
\hline IV & $\begin{array}{l}\text { Determining schedule for selecting } \\
\text { goods/services provider }\end{array}$ & $\begin{array}{l}\text { Bidding time frame is too short, } \\
\text { especially when it is too close to the end } \\
\text { of fiscal year }\end{array}$ & 2,130 \\
\hline V & $\begin{array}{l}\text { Drawing out of goods and services } \\
\text { procurement document }\end{array}$ & 2,150 \\
\hline & $\begin{array}{l}\text { Preparation and distribution of } \\
\text { procurement documents is inadequate }\end{array}$ & 2,490 \\
\hline VI & Determining owner estimated & $\begin{array}{l}\text { PPK has other tasks and assignments } \\
\text { which can act as distraction }\end{array}$ \\
\hline & 2 & $\begin{array}{l}\text { PPK does not do sufficient price survey } \\
\text { because of limited time and competency }\end{array}$ & 2,230 \\
\hline 3 & $\begin{array}{l}\text { Determining owner estimated based on } \\
\text { engineer estimate that is calculated by } \\
\text { consultant without repeated review }\end{array}$ & 2,110 \\
\hline 4 & $\begin{array}{l}\text { Bill of quantity does not match with the } \\
\text { construction work drawing }\end{array}$ & 2,030 \\
\hline
\end{tabular}

Source : researcher study, 2018 
Table 9. Frequent issues during bidding process

\begin{tabular}{|c|c|c|c|}
\hline No & & $\begin{array}{l}\text { Construction Bidding Issue in } \\
\text { Bidding Process Phase }\end{array}$ & Mean \\
\hline \multirow[t]{3}{*}{ II } & \multicolumn{2}{|c|}{$\begin{array}{l}\text { Registration and bidding } \\
\text { documents obtaining }\end{array}$} & \\
\hline & 1 & $\begin{array}{l}\text { Using other company's name to } \\
\text { join the tender process }\end{array}$ & 2,390 \\
\hline & 2 & $\begin{array}{l}\text { One person registers for many } \\
\text { corporations with different } \\
\text { usernames and company IDs }\end{array}$ & 2,030 \\
\hline \multirow[t]{2}{*}{ III } & \multicolumn{2}{|r|}{ Information session (aanwijzing) } & \\
\hline & & $\begin{array}{l}\text { Minimum involvement from } \\
\text { bidding participants especially at } \\
\text { technical construction work which } \\
\text { is tendered }\end{array}$ & 2,210 \\
\hline \multirow[t]{2}{*}{ VI } & \multicolumn{2}{|r|}{ Bid evaluation } & \\
\hline & & $\begin{array}{l}\text { Limitations of system, human } \\
\text { resources and regulation in bid } \\
\text { evaluation }\end{array}$ & 2,360 \\
\hline \multirow[t]{3}{*}{ VII } & \multicolumn{2}{|r|}{ Qualifications evaluation } & \\
\hline & 1 & $\begin{array}{l}\text { Lack of well-managed and } \\
\text { regularly-updated system and } \\
\text { database of contractors along with } \\
\text { the works they do and the } \\
\text { personnel involved in the works }\end{array}$ & 2,790 \\
\hline & 2 & $\begin{array}{l}\text { Inadequate expert needs in } \\
\text { quantity and expertise }\end{array}$ & 2,310 \\
\hline \multirow[t]{2}{*}{ VIII } & \multicolumn{2}{|c|}{ Qualification verification } & \\
\hline & & $\begin{array}{l}\text { Limitations of standar operational } \\
\text { system and regulation that support } \\
\text { qualification evaluation stage }\end{array}$ & 2,560 \\
\hline \multirow[t]{5}{*}{$\mathbf{C}$} & \multicolumn{2}{|c|}{ Rule/Regulation } & \\
\hline & 1 & $\begin{array}{l}\text { Lack of regulations for legal } \\
\text { protection of bidding executors }\end{array}$ & 2,664 \\
\hline & 2 & $\begin{array}{l}\text { Lack of synchronization among } \\
\text { regulations from Ministry of } \\
\text { Public Works, Ministry of Home } \\
\text { Affairs and the President, which } \\
\text { results in confusion }\end{array}$ & 2,638 \\
\hline & 3 & $\begin{array}{l}\text { The responsibility for goods and } \\
\text { services procurement process lies } \\
\text { fully with PPK }\end{array}$ & 2,368 \\
\hline & 4 & $\begin{array}{l}\text { Lack of standard in determining } \\
\text { the need for expert personnel in } \\
\text { the construction work }\end{array}$ & 2,257 \\
\hline
\end{tabular}

Source : researcher study, 2018

\subsubsection{Determining schedule for selecting goods/ services provider}

A too short period of time in tendering process can cause inadequacy of Pokja in bid evaluation. This issue typically occurs at or around the end of the fiscal year when changes in state budget are common, which then causing delay and uncertainty of the availability of construction work budget originating from the government.

\subsubsection{Drawing out of goods and services procurement document}

The common problems in this stage are the inadequate preparation and distribution of procurement documents.
The preparation of this document includes the incompleteness of technical requirements and specifications. Recently, the project management plan is considered to be important, nevertheles it has not been deemed as a requirement. The preparation of the inaccurate technical specifications may result in poor quality of delivery construction project. Procurement document distribution system is still manual and paperbased; this may affect the timing tender and constraints to monitor the status of e-tendering procces. It may take time to return and redistribute when the document is incomplete, unclear and requires changes

\subsubsection{Determining owner estimated (OE)}

In determining owner estimated stage, the most significant problems is PPK has other tasks and assignments, which can act as distraction. In Indonesian government, frequently PPK are inherent positions in structural positions, causing PPK is not focus on determining owner estimated. Besides that, the inherent position can also cause less competency in the construction implementation especially from nontechnical goverment regional organization (OPD) (eg health department, education departement). PPK is part of the non-technical OPD; its employees commonly do not required to have an undergraduate degree in engineering construction, with the result that not only they do not understand work itemization in budget estimate plan but also can not review construction planning documents. PPK was often found to submit documents to consultants without reviewing and pricing surveys. Inappropriate procedure in determining $\mathrm{OE}$ raises the problem of work volume discrepancy between budget estimate plan and construction shop drawings.

\subsubsection{Registration and bidding documents obtaining}

Using other company's name to join the tender process become a common issue. This affects the quality of construction works, especially when the contractor personnel does not have the required competencies as tender qualification. This can happen because of leakage of user and company ID in electronic procurement system (SPSE) intentionally and unintentionally. In addition, it can also happen because the participants use the services of others in terms of uploading and downloading bidding documents. This makes it possible that one person has and knows many users and IDs of construction providers.

\subsubsection{Information session (aanwijzing)}

Aanwizjing is not required to be followed by construction tender participants however this passive behavior is very impactful on the implementation of construction project. When participants did not find out the technical information about the implementation of construction project or did not conduct a field survey, the construction procces would not been understood. This certainly has an impact on quality and time of project delivery.

\subsubsection{Bid evaluation}

As shown in Table 8, the most frequent problems in this stage is limitations of system, human resources and regulation in bid evaluation. This includes the weakness 
of the procurement system and Standard Operation Procedure (SOP) to support bid evaluation process and limited human resource (pokja) in terms of number and competency. The system's weakness includes the inability to detect collusion among candidates because the evaluation process is only based on administrative documents. Furthermore, the system is not yet supported by a nationwide database that makes it possible to look at the list of all contractors and works that each of these contractors does. The system to evaluate the lowest price also has weakness where the candidates often drop their price bid solely to win tender while they disregard the quality of the work. In offering the lowest price for their bid, candidates use below-minimum wage to pay the labors. Pokja can not turn down this kind of bid since there is still no rules and standard regarding labors' wage.

\subsubsection{Qualifications evaluation}

As previously mentioned during offer evaluation, there is a need for a database that can provide a complete list of contractors, list of works each of these contractors undertake, work evaluation, past works done, and what kind of experts involved in the work. The absence of such database becomes an issue and it affects the amount of time it takes to do qualification evaluation. Without such database pokja is not able to ensure a contractor's basic competency in doing a particular work, which in turn will affect the quality and duration of the work. The second problem is limited experts in term of number and competency of construction project in Indonesia. This issue is related to the unavailability of standards and regulation that determining personnel skill requirements in construction project.

\subsubsection{Qualification verification}

The issues in this stage include the limited human resource, time and budget in doing the verification on the field. The most common occurrence is the difficulty in verifying the experts' competency and the employment status of the winning candidate's organization. Qualification verification process still can not detect misleading company name (In Indonesia, it is called as "pinjam bendera").

\subsection{Problem Mitigation}

Some mitigation ideas to solve these issues are based on the reformation concept done by LKPP as a government agency that makes decisions regarding procurement of goods and services in Indonesia. Four pillars of reformation are legislative and regulatory framework, institutional framework and management capacity, procurement operation and market practice, and integrity and transparency

\subsubsection{Legislative and regulatory framework}

In terms of rules and regulation, the most important thing that needs to be done immediately is the synchronization of all rules applied during the bidding process so that these rules can be in line with one another and not contradict each other. The creation of construction job standards needs to be completed with technical requirements, amount of labor required, and labor expertise requirements. It's also important to have assurance and legal protection for the managers of the bidding process, especially PPK and Pokja, so that there will be a clear distinction between legal and administrative actions

\subsubsection{Institusional framework and management capacity}

In term of Institutional framework and management capacity can be done by :

a. Improvement to human resources capacity in all involved elements of construction bidding, in government agencies, can be done by training to raise the level of the workforce's comprehension in construction work;

b. Recruiting pokja and asigning PPK which has technical and civil engineering background;

c. On the provider side, there needs to be improvement in contractor ecosystem to promote healthy competition and make it easier for new contractor to join the bidding process nationwide in Indonesia;

d. Certification for experts through exams and strict selection process;

e. Simplify the requirements to form a new corporation to increase number of construction provider and eliminate the practice of misleading company name (pinjam bendera);

f. Forming independent procurement unit within bidding process manager belongs in order to direct the focus on the job and not on other tasks.

\subsubsection{Procurement operation and market practice}

During bidding process, there needs to be a SPSE system that is integrated with a national database that stores list of contractors in Indonesia with information of their works, their personnel, and their performance evaluation. This way, it will be easier for pokja to evaluate tenders. Documents distribution can also be done with this system so that monitoring and bidding process are simpler and easier.

\subsubsection{Integrity and transparency}

To increase integrity and transparency, other than ethical codes and integrity pact that have existed, every step of the bidding process needs to involve APIP especially during the planning and bidding preparatory stages. High compensation for bidding executors can prevent corruptions / collusion / nepotism from happening.

\section{Conclusion}

During government construction bidding process there are still problems happening with a total number of 135 problems occurring. The most common problem is the bidding system's inability to provide a complete database of contractors with their personnel, works done, past experience and performance evaluation. In order to solve this issue, there needs to be an SPSE system that is integrated with nationwide contractors database. In addition, the limited human resources both in number and in competency is another important issue to consider. Improvement bidding executor's human resources quality and refinement in contractors ecosystem become very significant in a bidding process. In terms of rules and 
regulation, the most important thing needs to be done immediately is the synchronization of all rules applied during the bidding process so that these rules can be in line with one another and not contradict each other

\section{Acknowledgements}

Authors would like to show gratitude to Lembaga Pengelola Dana Pendidikan (LPDP) as the scholarship sponsor for this research and to respondents who participated in this study

\section{References}

1. D.J.Watt, B. Kayis, and K. Willey. Int. Jour. of Proj. Manag, 28, pp 51-60 (2010)

2. N. Semaan and M. Salem. Eng, Const.and Arc Manag, Vol. 24, No. 1, pp. 61-77. (2017),

3. S.S. Purwanto. J. Tek. Sipil, Vol. 9, No. 1, pp. 43-56. (2008),

4. M. Sohail, and S.Cavill. J.of Const. Eng. and Manag, Vol. 134, No. 9, pp. 729-738. (2008)

5. P.F. Kaming and D.Panuntun. Konferensi Nasional Teknik Sipil ke-6, Universitas Trisakti, Jakarta. (2012)

6. R. Mokoginta. https://rahfanmokoginta.wordpress.com. (2012)

7. W.H. Chang and J.S. Chang, Elec. Commerce Research and Applications, Vol. 11, pp. 346-360. (2012)

8. A.A Costa, A Arantes, and L.V Tavares. J.of Purch \& Supp. Manag, Vol. 19, pp. 238-246. (2013),

9. D.A Wibawa. http://www.bppk. kemenkeu .go.id/publikasi/artikel (2014)

10. T. Hanak and P. Muchova . Procedia Computer Science, Vol. 64, pp. 729- 735. (2015)

11. I.A. Faisol, Tarjo and S. Musyarofah, J. Pemikiran Pen. Eko. Vol. 4, No. 1, pp. 1-21. (2015)

12. S.Kautsariyah and S. Hardjomuljadi. J. Konstr., Vol. 8, No. 1, pp. 75-86. (2016).

13. A. Maulidi. Int J. of Economics and Financial, Vol. 7, No. 2, pp. 145-154. (2017).

14. Peraturan Presiden Nomor 54. tentang Pengadaan Barang/Jasa Pemerintah. (2010)

15. Peraturan Presiden Nomor 70 tentang Perubahan Kedua atas Peraturan Presiden Nomor 54 Tahun 2010 tentang Pengadaan Barang/Jasa Pemerintah. (2012)

16. J. Sarwono. Metode Riset Skripsi Pendekatan Kuantitatif (Menggunakan Prosedur SPSS). (2012)

17. R.A Wibowo. J. Integritas, Vol. 1, No. 1, pp 37-60. (2015)

18. Syariffudin. E-jurnal Katalogis, Vol. 3, No. 11, pp. 24-38 (2015)

19. Y. Zhang, H. Luo, and Y. He .Procedia Engineering, Vol. 123, pp. $606-614$ (2015)

20. A. Sutedi. Aspek Hukum dalam Pengadaan Barang \& Jasa and Berbagai Permasalahannya, Edisi kedua, (2012)
21. M. Shan, A.P.C Chan, Y. Le, Y.Hu, and B. Xia. J.of Prof Issues in Eng. Educ.and Prac. Vol. 143, No.3, pp. 05016012. (2017)

22. B Sichombo, M. Muya, W. Shakantu, and C. Kaliba. Int. Jour. of Proj. Manag. Vol. 27, No. 8, pp. 821-832 (2009)

23. M.Ajam, M. Alshawi, and T. Mezher. Automation in Const., Vol. 19, pp. 762-778. (2010)

24. J.B.H Yap, H.A. Rahman, and W.Chen. Int. Jour. of Proj. Manag, Vol. 35, pp 1253-1271. (2017),

25. D.R Cooper, and P.S. Schindler. Business Research Methods, 9th edition. (2006).

26. R.Kountur. Metode Penelitian untuk Penulisan Skripsi and Tesis, Cetakan kedua. (2004)

27. A.G. Yong, and S. Pearce, S. A beginner's guide to factor analysis: focusing on exploratory factor analysis. 9(2):79-94. (2013) 